\title{
Anna Brickhouse
}

The Unsettlement of America: Translation, Interpretation, and the Story of Don Luis de Velasco, 1560-1945. Imagining the Americas 7. New York: Oxford University Press, 2015. Pp. xiii +366 . Hb, \$69.

The Unsettlement of America is a very apt addition to Oxford University Press's interdisciplinary series on the Americas. It is, in part, a case study of the factors that can shape the interpretations and manipulations of an historical event over the course of several centuries, as well as a reflection on both the opportunities and dangers of methodology and theory applied to the transatlantic and hemispheric areas notated by "American Studies." The event is the brief, tragic history of the Spanish Jesuit attempt to begin a mission in 1570 in "Ajacán," on what the English will forty years hence call the Rappahannock River in their colony of Virginia. When a ship arrives to resupply the nascent colony the following spring, there is no trace of the Jesuits. A young lay worker, apparently the sole survivor, reports that the missionaries have been the victims of their indigenous, European-educated pilot-interpreter, don Luis de Velasco, who has vanished along with the Black Robes. It marks the end of the Spanish attempt to secure a foothold on the North American coastline above Florida, but only the beginning of the long historiographical quest to recover the motive for the native translator's treachery and the significance of this aborted colonization.

Brickhouse traces the historiography that grew out of this event in three eras. First in her survey are the sixteenth-century accounts of the failed mission by Jesuits and Spanish colonial officials, most of which demonized don Luis over his murderous behavior which had made martyrs of his benefactors. At the same time they ignored the central role he had had in shaping the narrative upon which their own accounts depended. Other accounts challenged this hagiographical explanation, such as Gómez Suárez de Figueroa's subversive justification of don Luis's violent resistance by implying that evangelization is a form of imperialism. This phase of unsettlement history culminates in Juanillo's Rebellion in Florida in 1597 which led to a virtual Spanish moratorium on further colonization in Florida that lasted well into the seventeenth century.

The second era of don Luis historiography involves his nineteenth-century discovery by English speakers in the New World. Robert Greenhow, employed by the Polk administration as a translator in the State Department, uses a "journal" that was the literary child of Edgar Allen Poe to advance the claims of the United States to the Oregon Territory. In his eagerness to use invented history in the service of national expansion, Greenhow failed, or chose not, to notice the irony in Poe's telling that makes the "journal” disprove any American claim 
to prior discovery. Worse yet was Greenhow's self-censorship in his 1848 memoirs of any mention of the failed Spanish Virginia colony so as not to complicate negotiations between the United States and Mexico over land claims. It fell to the Catholic proto-historian, John Gilmary Shea, to introduce don Luis and the Jesuit mission in Virginia to American readers at the very outbreak of the Mexican-American War in 1846. Forty years later, Alice Fletcher, an amateur anthropologist working for the Department of the Interior, used the don Luis story as an indictment of the Spaniards' relations with Native Americans. Her report for the us Senate paved the way for the passage of the notorious Dawes Act in 1887.

The Don Luis story reemerged just as the United States was caught up in the Second World War. The vehicle was James Branch Cable's novel, which featured don Luis in the title role of The First Gentleman of America, who poses as a promoter of Franklin Roosevelt's Good Neighbor Policy but in doing so undermines the racial harmony and inter-hemispheric cooperation that the policy purports to promote.

The Unsettling of America is also an epistemological inquiry, a study of the various channels by which knowledge is acquired and exchanged, including its inherent opaqueness as well as an openness to distortion, suppression, and falsification. The intellectual history of don Luis in Ajacán serves as a metaevent in which epistemology shapes history across the centuries. It provides Brickhouse with a model for a longue durée methodology for American Studies that is truly hemispheric. The bilingual mastery and transatlantic experience of translators enabled them to have a privileged access to the expanding knowledge that European-American interactions were making possible. It was precisely don Luis's discovery of the brutal consequences, including the forced labor and enslavement of Spanish colonization of America that, Brickhouse infers, led him to turn against the Jesuits who had trained and nurtured him. Treachery was the price he was willing to pay to save his people from what Spanish greed would eventually inflict upon them, no matter how selfless and well-intended the Jesuit mission was. As noted earlier, one of Brickhouse's central contentions is that the translator was the one controlling the narrative, not simply conveying it. In scrutinizing any translated text according to its full context she finds that the "motivated mistranslation" was not simply a means adopted by Velasco to impede colonization, but was the "default condition" for all translation in colonial America as well as "in many of the subsequent literary and historical writings that have sought to represent it" (5).

From the very beginning the Spaniards had recognized the importance of reliable translation in creating and extending their empire in the Americas. In order to have maximum control of the translation and interpretation that was 
so critical to any successful interaction with Natives, the Spanish, from Columbus on, regularly kidnapped Indians to train them (often in Europe) to serve as translators. This highly self-conscious group, although its cultural environment was very much the Atlantic world, in Brickhouse's reading, used their linguistic skills to impede, not facilitate settlement in the Americas.

Her inferences of the "elusive subtext" are by her own admission often speculative, but a mastery of the thick context and the full utilization of a deft imagination provide astute, provocative insights into the reconstruction of events. In a few places, her desire to prove her thesis leads her into some tortuous conjectures or wrenched readings at odds with the text's face value. And the general conclusion she reaches about this enterprise of unsettlement goes farther than her overall carefully construed exegesis of particular texts would predict. "The story of Don Luis de Velasco," she states, "is a story about the indigenous production of knowledge [...], a translator's wresting of narrative control from the text's very writers" (93). By shifting the traditional portrayal of the indigenous person as the one about whom the story is told to that of becoming the major voice in the narrative she appears to reject one extreme position only to promote its polar opposite, the intellectual warrior in behalf of unsettlement.

But such noddings are rare. This is a sweeping tour de force that deserves a broad circulation, particularly among those drawn to cutting-edge works of which this is an outstanding exemplar.

Robert Emmett Curran

Georgetown University

Rcurrano72@roadrunner.com

DOI 10.1163/22141332-00303008-15 